\title{
ASSESSMENT OF SPOT SATELLITE DATA FOR TROPICAL VEGETATION INVENTORY AND MONITORING IN SUMATRA
}

\author{
Y. LAUMONIER and U..R. DJAILANY - SYAFII \\ Tropical Forest Biology Programme, SEAMEO-BIOTROP Bogor, \\ Indonesia
}

\begin{abstract}
Following a previous vegetation mapping in Sumatra island (Indonesia), an assessment of SPOT satellite capability to handle specific problems related to vegetation identification and monitoring from remote sensing data has been undertaken.

Results of visual interpretation and multispectral analysis have shown the usefulness of SPOT data for the appraisal of tropical vegetation at medium scale. This was particularly striking for the swampy vegetation types including mangroves and for the secondary vegetation, for which significant improvements have been brought by multispectral classifications. A $20 \mathrm{~m}$ ground resolution is neither sufficient to provide information on primary forest patterns, nor to identify properly logged over areas. Nevertheless, several degrees of depletion of the forest and all the serial stages have been identified, which is a considerable progress compared with previous remote sensing means.

SPOT is a very good alternative to medium scale aerial photographs for the production of medium scale $(1: 100000$ to $1: 250000)$ vegetation and land-use maps.
\end{abstract}

\section{BACKGROUND AND JUSTIFICATION}

Since 1980 BIOTROP, the SEAMED Regional Centre for Tropical Biology, has conducted not only a mapping inventory of land-use units and natural vegetation types in Sumatra which involves remote sensing analysis, but also very detailed field studies on various plant formations and their dynamics, floristics, structure and ecology. Results have been synthesized in the form of ecological vegetation maps (Laumonier 1983, Laumonier et al. 1986, 1987) and related surveys (Laumonier 1981, Blasco et al. 1983).

The mapping was mostly done using conventional means, i.e. interpretation of a 1/100 000 scale panchromatic aerial photograph cover (1974-78) which appeared to be of rather poor quality. Moreover, the Landsat MSS imageries have proved insufficient in discriminating many peculiar vegetation or land-use types. This necessitated an unusually detailed field work to supplement the lack of information obtained from space, but it gave researchers of the team a fairly good knowledge of the area.

The second phase of the BIOTROP study implemented in 1988 is concerned with specific areas selected according to management problems spotted during the small-scale mapping phase. Such development schemes would require an elabora- 
- various shrubby secondary vegetation types identical from space, but floristically entirely different often mixed with cultivation and usually classified as "mosaics".

\section{A. Visual interpretation and manual classification}

The visual interpretation of black and white prints allows to differentiate 19 landcover and vegetation units (Table 4 and Figure 3). The standard FCC gives less information compared with the black and white interpretation of the 3 bands. Improved false colour composites (XS - Bi - Vgi and XS3 - Bi - Vgi) allow a better discrimination of secondary types, burnt or newly planted areas.

\section{B. Digital classification}

For the scene of Pasirmayang, a multispectral classification has been performed for two windows, one in Pasirmayang area (512 x 512 pixels) corresponding mostly to natural vegetation cover, the other in Sitiung area (512 x 512 pixels) consisting of cultivation and settlements.

XS1, XS2 and XS3 means and standard deviations plotted on bi-dimensional diagrams provide a satisfactory discrimination of vegetation and land cover units (Figure 4). In Pasirmayang window, 10 classes corresponding to 6 vegetation types and 4 other land-use units were recognized (Figure 4, Plate 2), whereas in Sitiung 5 vegetation types and 3 land-use units could be distinguished (Figure 4, Plate 3).

Table 4. Classification of vegetation in Muarabungo's lowland area by visual interpretation

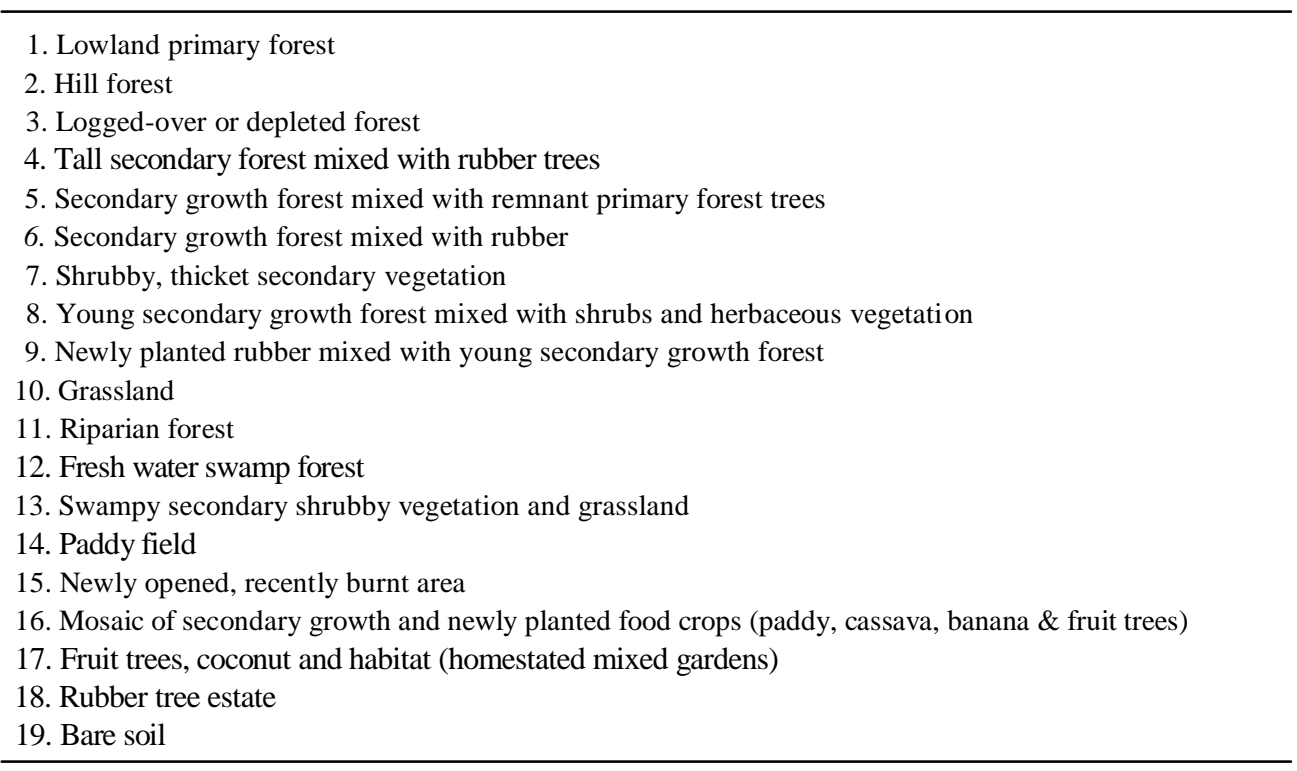


tion of larger scale vegetation and land-use maps and more precise knowledge and understanding of the land-use patterns identified on remote sensing documents. The very high ground resolution obtained with SPOT offers new perspectives in the mapping of those patterns. A first evaluation of such data was initiated during the PEPS program (Programme devaluation Preliminaire de SPOT) organized by the French Space Agency (Laumonier et al. 1987). Its aim was to assess the capabilities of SPOT satellite to tackle some of the most striking problems met during the first phase of the project in Sumatra, specially with the identification and classification of vegetations and land-use units.

The present study is a follow up of this investigation backed up by related researches (Barkey 1987, Djailany 1987, Gastellu-Etchegorry 1988) concerned with an evaluation of visual versus digital interpretations and classifications, a comparison of SPOT data with conventional aerial photographs and Landsat MSS data already analyzed in the area (Deshayes 1981, Ducros-Gambart \& Gastellu-Etchegorry 1984, Ducros-Gambart et al. 1984) and an assessment of panchromatic (P) versus multi-spectral (XS) mode. It is also supported by the ground sampling already completed by the BIOTROP team for the characterization of complex heterogeneous success-ional stages, primary forest patterns and land-use units in Sumatra (Laumonier 1981, Torquebiau 1986, Djailany 1987).

\section{MATERIALS AND METHODS}

Four scenes have been requested both in $\mathrm{P}$ and XS modes at the processing level 1B (Table 1) corresponding to specific problem areas in Central and South Sumatra (Figure 1). The Muarabungo area (Western part of Jambi province) has been chosen as an example of a forested area with problems of local agricultural practices and modern plantation schemes. Baturaja (South Sumatra) is the test site for another type of land use where the original vegetation has almost disappeared and has been replaced by complex secondary types. Lastly, the delta of Musi-Banyuasin was selected as a good example of management problems in swampy areas.

The completion of data acquisition during the requested period (1986) occurred over a region where the cloud cover was always very high at the equator. The SPOT lateral viewing capability could be responsible for the relative ease in their acquisition.

The materials used in the study included Computer Compatible Tapes (CCT), negative films at 1/400 000 and 1/200 000 scales for each XS band, standard false colour composites ( 2 scenes only) at 1/80 000 or 1/100 000 scales, and negative films at 1/200 000 in panchromatic mode. 


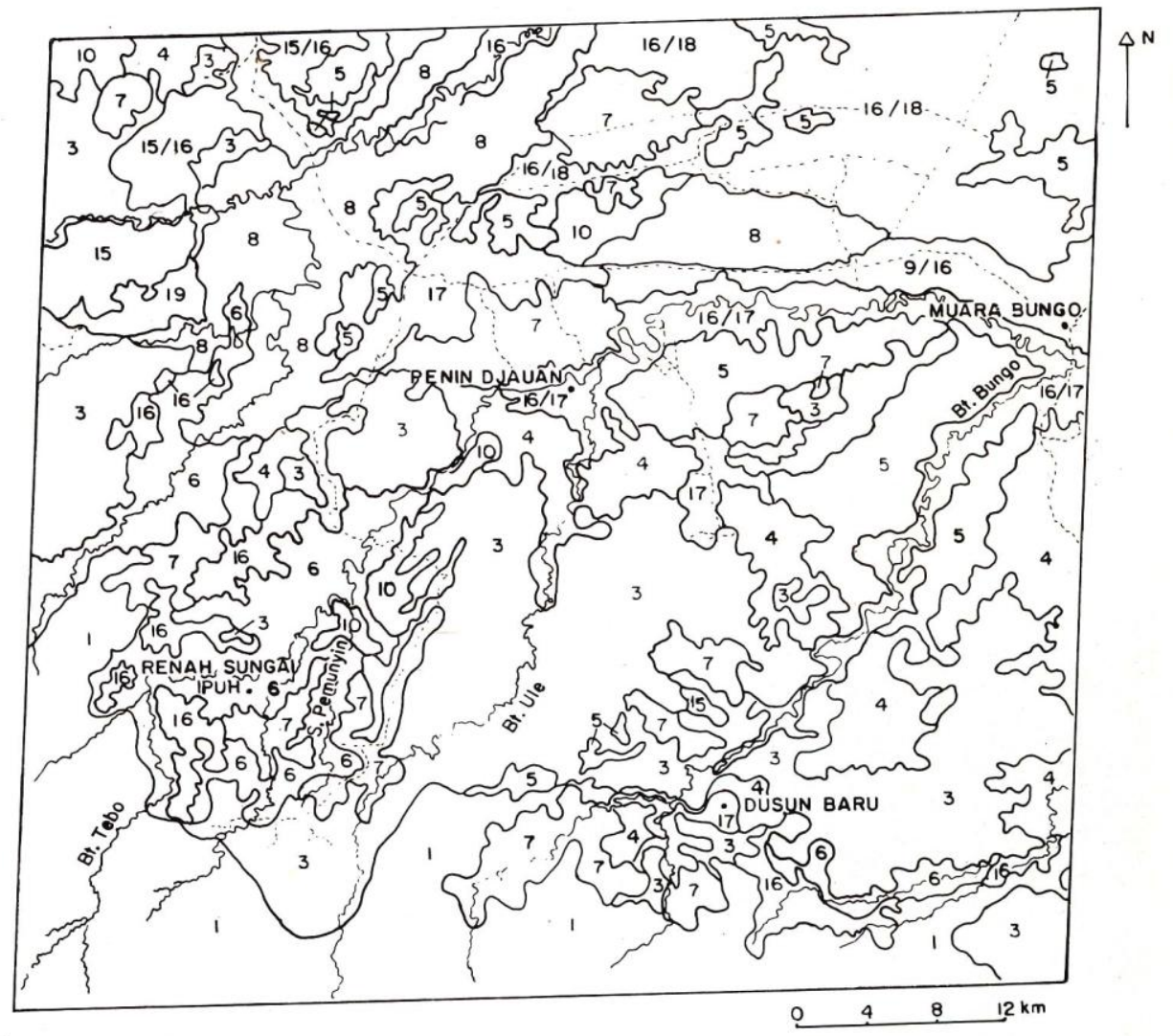

Figure 3. Manual interpretation of vegetation types and land-use units on the black and white SPOT imageries, scale 1/40 000, 1986 (Legend see Table 4). 


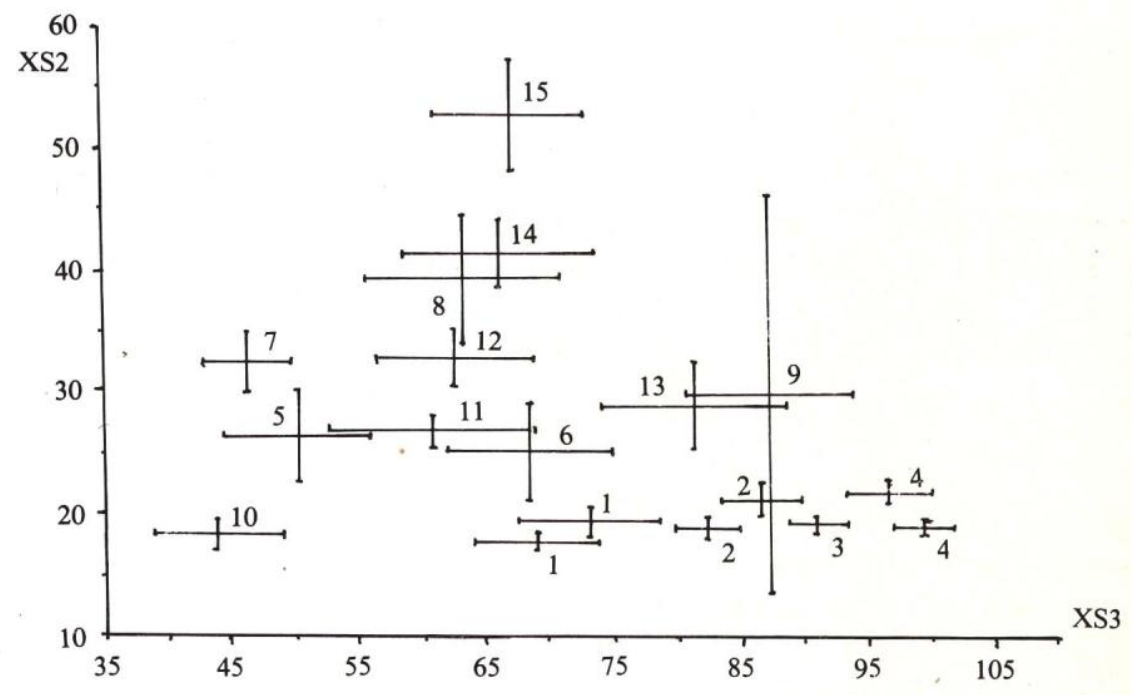

Figure 4. XS3/XS2 diagram of the 15 spectral classes selected in Pasir Mayang scene

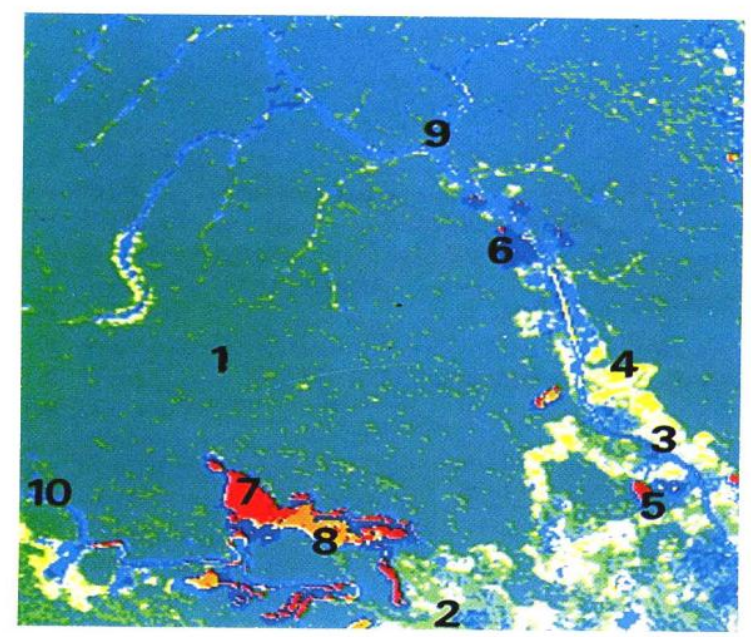

Legend: Pasir Mayang

1. Logged-over or depleted forest

2. Tall secondary forest mixed with rubber

3. Secondary growth forest mixed with rubber

4. Rubber tree estate

5. Inundated area

6. Newly opened, recently burnt ("shifting cultivation") area

7. Newly opened, clear felled forest for "shifting cultivation"

8. Newly planted food-crops (dry soil slightly covered by vegetation)

9. Logging road

10. River

Plate 2. Multispectral classification of window Pasir Mayang (512 x 512 pixels) 


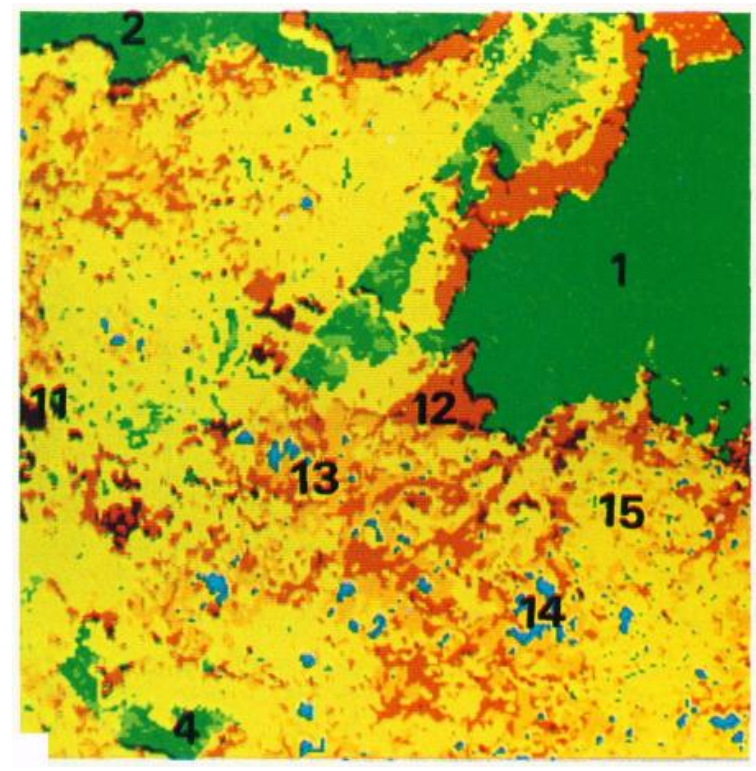

Legend: Sitiung

1. Logged-over or depleted forest

2. Tall secondary forest mixed with rubber

4. Rubber tree estate

11. Recently burnt area

12. Burnt area long time ago

13. Open dry field and shrubby vegetation

14. Gardens mixed with food-crops

15. Habitation

Plate 3. Multispectral classification of window Sitiung (512 x 512 pixels)

The multispectral analysis has brought additional information for some nonvegetated types $(5,7,11,12,15$; Table 5) which are more or less homogeneous or difficult to separate properly on the black and white prints. The too long period of time separating data acquisition from field check and the dynamic nature of the land use unit types have hampered the proper evaluation of the results of the classification. Some areas classified as "dry open fields" in July 1986 appeared to be rainfed paddy areas in October 1987. All burnt areas (shifting cultivation) face similar problems in that, the spectral response varies a lot between nearby windows (types 11 and 12 in Sitiung and in Pasirmayang for instance). Once again, the problem of having the same spectral value for entirely different object on two different windows and viceversa hampered the classification in Figure 4. The confusion between classes 8 and 14 or 9 and 13 is obvious. The haze occurring in the Sitiung area may be responsible for the slightly different spectral values compared with the same object in Pasirmayang. A general classification cannot be applied to these two windows. Moreover, the very simple classification method used may be responsible for some difficulties in separating the objects. Separation of spectral value using the box classification method faces the problem of a statistical distribution represented by the standard deviation of the centre point of the box. Furthermore, 
BIOTROPIA No. 3, 1989/1990

Table 5. Spectral characteristics of the 15 classes, defined on a $2 \times(512 \times 512$ pixels $)$ of Pasirmayang scene

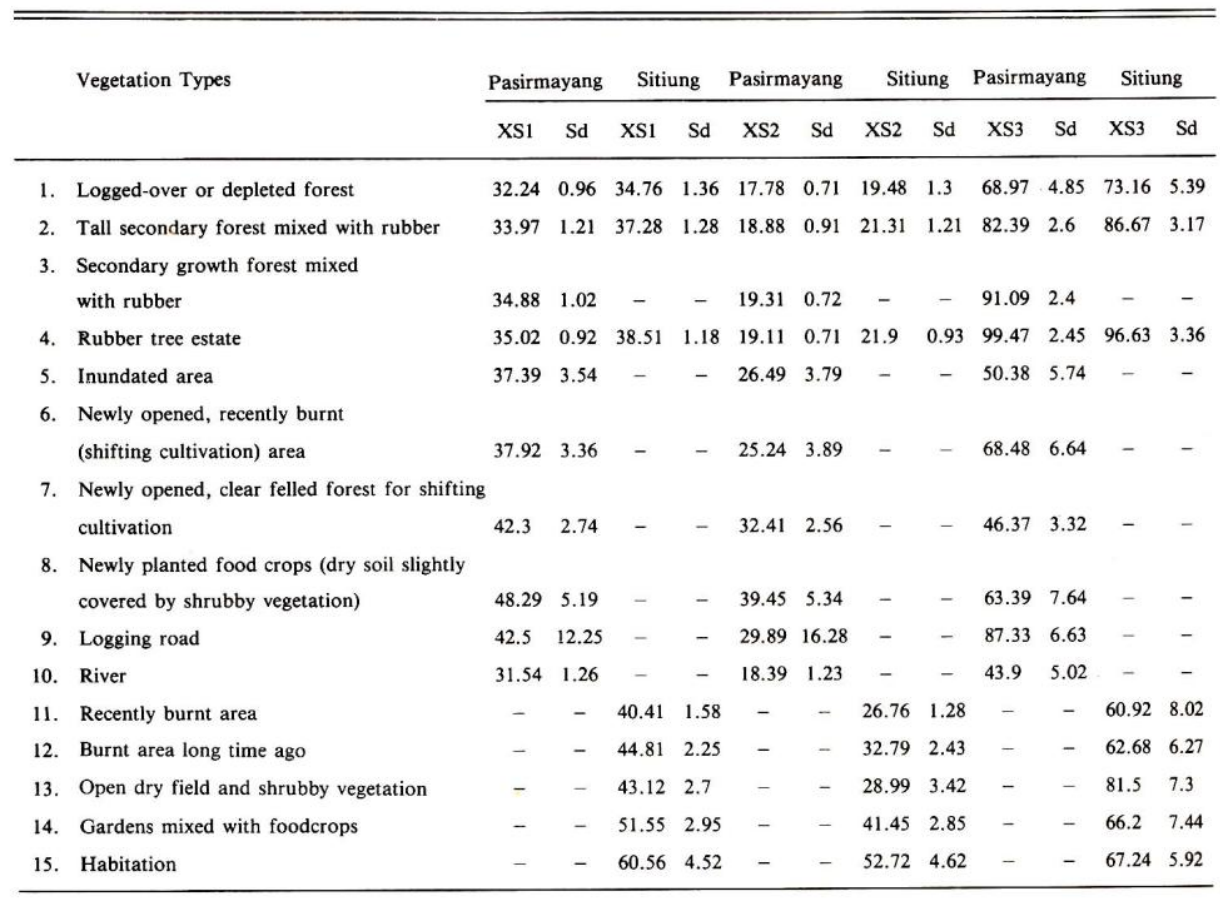

unknown spectral values are always classified into smaller box and this results in unsolved problems in decision boundaries delineation in a bi-dimensional space.

In the Muarabungo scene, three windows have been chosen (Sei Pemunyin 1 and 2, Rimbo Bujang), each of 512 x 512 pixels. The first two corresponds mainly to tropical rain forest and its degradation types, the third (Rimbo Bujang) to agricultural landcover types found in transmigration areas.

For this scene, the box classification of XS1, XS2 and XS3 means and standard deviations gathered from the three windows gives 18 classes, 13 representing vegetation types, and 5 corresponding to open areas, roads and rivers (Figure 5 and Table 6).

Results are very similar to those of Pasirmayang. Implementation of that classification into each window needs some adjustments to avoid misclassification. Plate 4, Table 7 and Plate 5, Table 8, are the results of such an implementation. The same problems of some pixel being not classified as in Pasirmayang scene has occurred.

Compared with the classification by visual interpretation of the black and white prints, certain classes $(11,12,13$; Table 4$)$ are very difficult to identify properly in the digital classification process. 
Assessment of spot satellite data-Y. Laumonier \& U.K. Djailany-Syafii

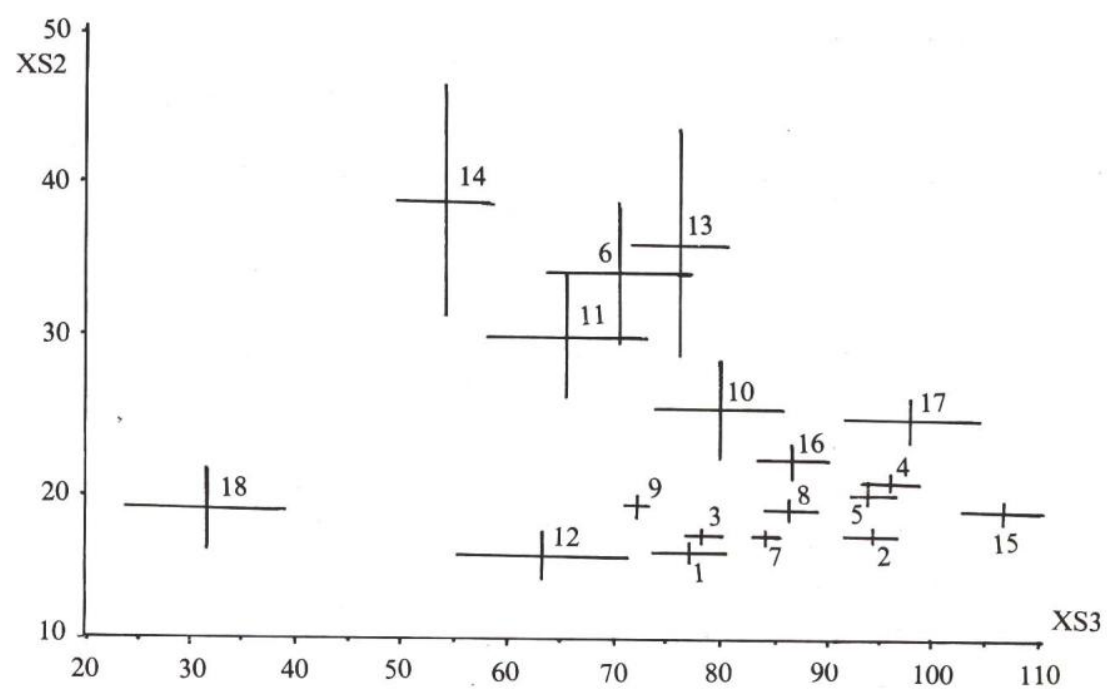

Figure 5. XS3/XS2 diagram of the 18 spectral classes selected in Muarabungo scene.

Table 6. Spectral characteristics of the 18 classes, defined on a $3 \times(512 \times 512$ pixels $)$ of Muarabungo scene

\begin{tabular}{lrllllll}
\hline \hline Vegetation Types & Pixels & XS1 & Sd1 & XS2 & Sd2 & XS3 & Sd3 \\
\hline 1. Lowland primary forest & 1730 & 30.83 & 2.12 & 16.2 & 1.44 & 76.81 & 7.08 \\
2. Logged-over or depleted forest & 72 & 33.08 & 1 & 17.51 & 0.88 & 93.94 & 5.4 \\
3. Tall secondary forest mixed with rubber trees & 2690 & 32.52 & 1.21 & 17.51 & 1.27 & 78.14 & 6.84 \\
4. Young secondary forest & 370 & 37.76 & 1.11 & 20.99 & 1.07 & 95.82 & 4.96 \\
5. Secondary growth forest mixed with rubber & & & & & & & \\
and shrubs & 1469 & 35.88 & 2.39 & 20.24 & 1.76 & 93.62 & 5.63 \\
6. Newly opened, recently burnt area & 238 & 42.51 & 5.42 & 34.38 & 9.76 & 70.32 & 13.64 \\
7. Secondary growth forest mixed with remnant & & & & & & & \\
primary forest trees & 713 & 32.09 & 1.01 & 17.28 & 0.78 & 84.12 & 5.63 \\
8. Mosaic of food crops and sparse fruit trees & 893 & 34.62 & 1.45 & 19.02 & 1.32 & 86.33 & 5.13 \\
9. Rubber tree estate & 240 & 32.66 & 0.83 & 19.14 & 1.12 & 72.05 & 2.49 \\
10. Newly opened, recently burnt area & 330 & 39.31 & 4.32 & 25.56 & 6.46 & 79.71 & 12.22 \\
11. Fruit trees, coconut and habitat (homestated & & & & & & & \\
mixed gardens) & 401 & 40.72 & 4.9 & 30.18 & 8.04 & 65.53 & 15.42 \\
12. Riparian forest & 452 & 29.97 & 1.19 & 15.91 & 0.98 & 63.05 & 8.18 \\
13. Road & 162 & 44.36 & 4.88 & 36.46 & 7.66 & 76.09 & 4.59 \\
14. Bare soil & 99 & 44.19 & 7.08 & 39.09 & 15.35 & 54.23 & 15.18 \\
15. Shrubs and grassland alang-alang & 406 & 35.64 & 0.92 & 19.14 & 0.79 & 106.4 & 7.81 \\
16. Newly planted rubber mixed with young se- & & & & & & & \\
condary growth forest & 214 & 37.75 & 2.3 & 22.23 & 2.31 & 86.6 & 6.88 \\
17. Herbaceous and slightly open area & 120 & 42.23 & 2.61 & 25.07 & 2.94 & 97.74 & 12.99 \\
18. Rivers & 15 & 32.06 & 8.34 & 18.6 & 5.64 & 31.26 & 15.68 \\
\hline
\end{tabular}




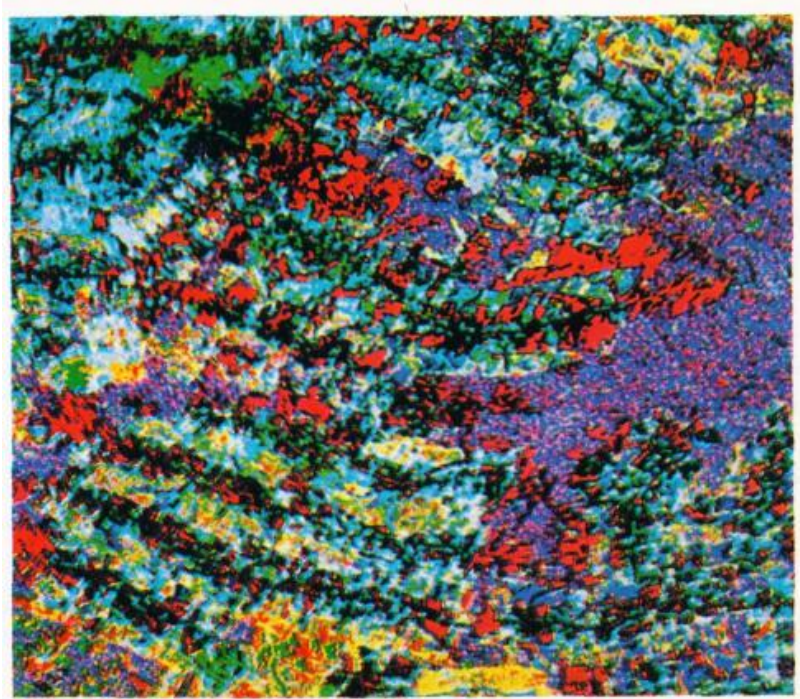

Plate 4. Digital classification of window Rimbo Bujang, Muarabungo

Table 7. Digital classification of Rimbo Bujang, Muarabungo

\begin{tabular}{|c|c|c|c|c|c|}
\hline Class & Vegetation Types & Pixels & $\begin{array}{l}\text { Surface } \\
\text { (ha) }\end{array}$ & $\begin{array}{l}\text { Percentage } \\
(\%)\end{array}$ & Colour \\
\hline$\overline{1}$ & Unclassed & 5953 & 238.12 & 2.3 & black \\
\hline 2 & Logged-over or depleted forest & 16283 & 651.32 & 6.2 & red \\
\hline 3 & $\begin{array}{l}\text { Tall secondary forest } \\
\text { mixed with rubber trees }\end{array}$ & 9648 & 385.92 & 3.7 & $\begin{array}{l}\text { whitish } \\
\text { (bright) red }\end{array}$ \\
\hline 5 & $\begin{array}{l}\text { Secondary growth forest } \\
\text { mixed with rubber and shrubs }\end{array}$ & 24661 & 986.44 & 9.4 & $\begin{array}{l}\text { pale } \\
\text { pink }\end{array}$ \\
\hline 7 & $\begin{array}{l}\text { Secondary growth forest } \\
\text { mixed with remnant primary } \\
\text { forest trees }\end{array}$ & 5940 & 237.6 & 2.3 & green \\
\hline 8 & $\begin{array}{l}\text { Mosaic of food crops and } \\
\text { sparse fruit trees }\end{array}$ & 20400 & 816 & 7.8 & $\begin{array}{l}\text { yellowish } \\
\text { green }\end{array}$ \\
\hline 9 & Rubber tree estate & 31970 & 1278.8 & 12.2 & violet \\
\hline 10 & $\begin{array}{l}\text { Newly opened, recently } \\
\text { burnt area }\end{array}$ & 62956 & 2518.24 & 24 & brown \\
\hline 11 & $\begin{array}{l}\text { Fruit trees, coconut and } \\
\text { habitat (homestated mixed } \\
\text { gardens) }\end{array}$ & 26999 & 1079.96 & 10.3 & $\begin{array}{l}\text { dark } \\
\text { purple }\end{array}$ \\
\hline 15 & $\begin{array}{l}\text { Shrubs and grassland } \\
\text { alang-alang }\end{array}$ & 8315 & 332.6 & 3.2 & yellow \\
\hline 16 & $\begin{array}{l}\text { Newly planted rubber } \\
\text { mixed with young secondary } \\
\text { growth forest }\end{array}$ & 37104 & 1484.16 & 14.2 & $\begin{array}{l}\text { whitish } \\
\text { grey }\end{array}$ \\
\hline 17 & $\begin{array}{l}\text { Herbaceous and slightly } \\
\text { open area }\end{array}$ & 11915 & 476.6 & 4.5 & $\begin{array}{l}\text { dark } \\
\text { yellow }\end{array}$ \\
\hline
\end{tabular}


Assessment of spot satellite data-Y. Laumonier \& U.R. Djailany-Syafii

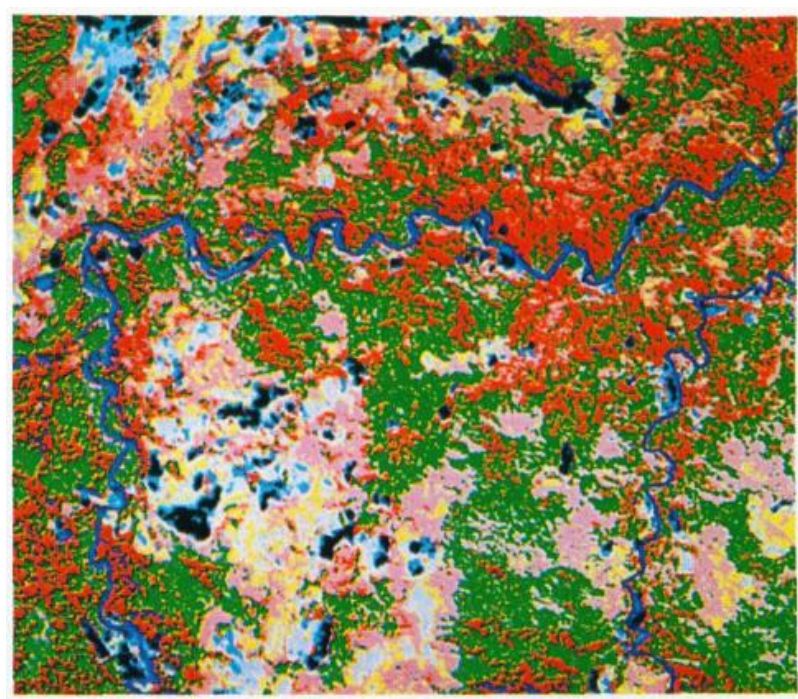

Plate 5. Digital classification of window Sei Pemunyin, Muarabungo

Table 8. Digital classification of window Sei Pemunyin, Muarabungo

\begin{tabular}{|c|c|c|c|c|c|}
\hline Class & Vegetation Types & Pixels & $\begin{array}{l}\text { Surface } \\
\text { (ha) }\end{array}$ & $\begin{array}{l}\text { Percentage } \\
(\%)\end{array}$ & Colour \\
\hline$\overline{0}$ & Unclassed & 723 & 28.92 & 0.3 & black \\
\hline 1 & Lowland primary forest & 21623 & 864.92 & 8.3 & red \\
\hline 2 & $\begin{array}{l}\text { Logged-over or depleted } \\
\text { forest }\end{array}$ & 62353 & 2494.12 & 23.8 & $\begin{array}{l}\text { pale } \\
\text { pink }\end{array}$ \\
\hline 3 & $\begin{array}{l}\text { Tall secondary forest } \\
\text { mixed with rubber trees }\end{array}$ & 49591 & 1983.64 & 18.9 & $\begin{array}{l}\text { bright } \\
\text { red }\end{array}$ \\
\hline 4 & Young secondary forest & 11824 & 472.96 & 4.5 & $\begin{array}{l}\text { whitish } \\
\text { (bright) red }\end{array}$ \\
\hline 7 & $\begin{array}{l}\text { Secondary growth forest } \\
\text { mixed with remnant primary } \\
\text { forest trees }\end{array}$ & 79407 & 3176.28 & 30.3 & green \\
\hline 10 & $\begin{array}{l}\text { Newly opened, recently } \\
\text { burnt estate }\end{array}$ & 7042 & 281.68 & 2.7 & brown \\
\hline 15 & $\begin{array}{l}\text { Shrubs and grassland } \\
\text { alang-alang }\end{array}$ & 11840 & 473.6 & 4.5 & yellow \\
\hline 16 & $\begin{array}{l}\text { Newly planted rubber } \\
\text { mixed with young secondary } \\
\text { growth forest }\end{array}$ & 7191 & 287.64 & 2.7 & $\begin{array}{l}\text { whitish } \\
\text { grey }\end{array}$ \\
\hline 17 & $\begin{array}{l}\text { Herbaceous and slightly } \\
\text { open area }\end{array}$ & 2885 & 115.4 & 1.1 & $\begin{array}{l}\text { dark } \\
\text { yellow }\end{array}$ \\
\hline 18 & River & 7665 & 306.6 & 2.9 & blue \\
\hline
\end{tabular}




\section{Sungai Sembilang — Banyuasin delta}

Sungai Sembilang - Banyuasin delta has undergone drastic changes since it has been chosen as a pilot area for transmigration resettlement. In spite of the numerous development aid studies conducted there, it still needs an urgent and accurate monitoring. Mangroves used to flourish in the area and the remaining ones are likely to suffer from high population pressure in the future if not managed properly now. Besides the mangrove belt, the lowland plain is consisting of extensive peat swamps which are also very difficult to manage for agricultural purposes.

Vegetation types which are often difficult to identify and segregate properly are:

- The mangrove forest and the adjacent fresh water swamp forest just behind it (this usually leads to an over-estimation of the actual mangrove area).

- The fresh water swamp forest on alluvium or shallow peat and the peat swamp forest itself on deeper peat soils, altogether with various peat swamp forest types.

- The swampy grasslands and the paddy fields occurring within swampy areas.

- The various secondary shrubby swamp vegetation types and the low natural "pole" swamp forest which look identical when seen from the air. Important to investigate also is the proper identification of such secondary vegetation types like the "Gelam" (Melaleuca cajuputi) formations.

\section{A. Interpretation and manual classification}

The visual interpretation gives very interesting results as all the types are perfectly distinct (12 land cover types), from mangrove swamps, fresh water swamp forest and various peat swamp forest types.

\section{B. Digital classification}

The multispectral classification performed with SPOT gives 9 classes among which 6 are vegetation types (Plates $6 a \& 6 b$ ). Several types or communities are visible within the mangrove itself, and the distinction between mangroves and fresh water swamp forest is easy.

\section{Possible applications}

1. Well-drained lowlands

a) Primary lowland forest

Appraisal of the mosaic patterns was studied in panchromatic mode at 1/50 000 scale and with multispectral data. It was impossible in any case to recognize any pattern even if some degrees of natural disturbance could be pointed 

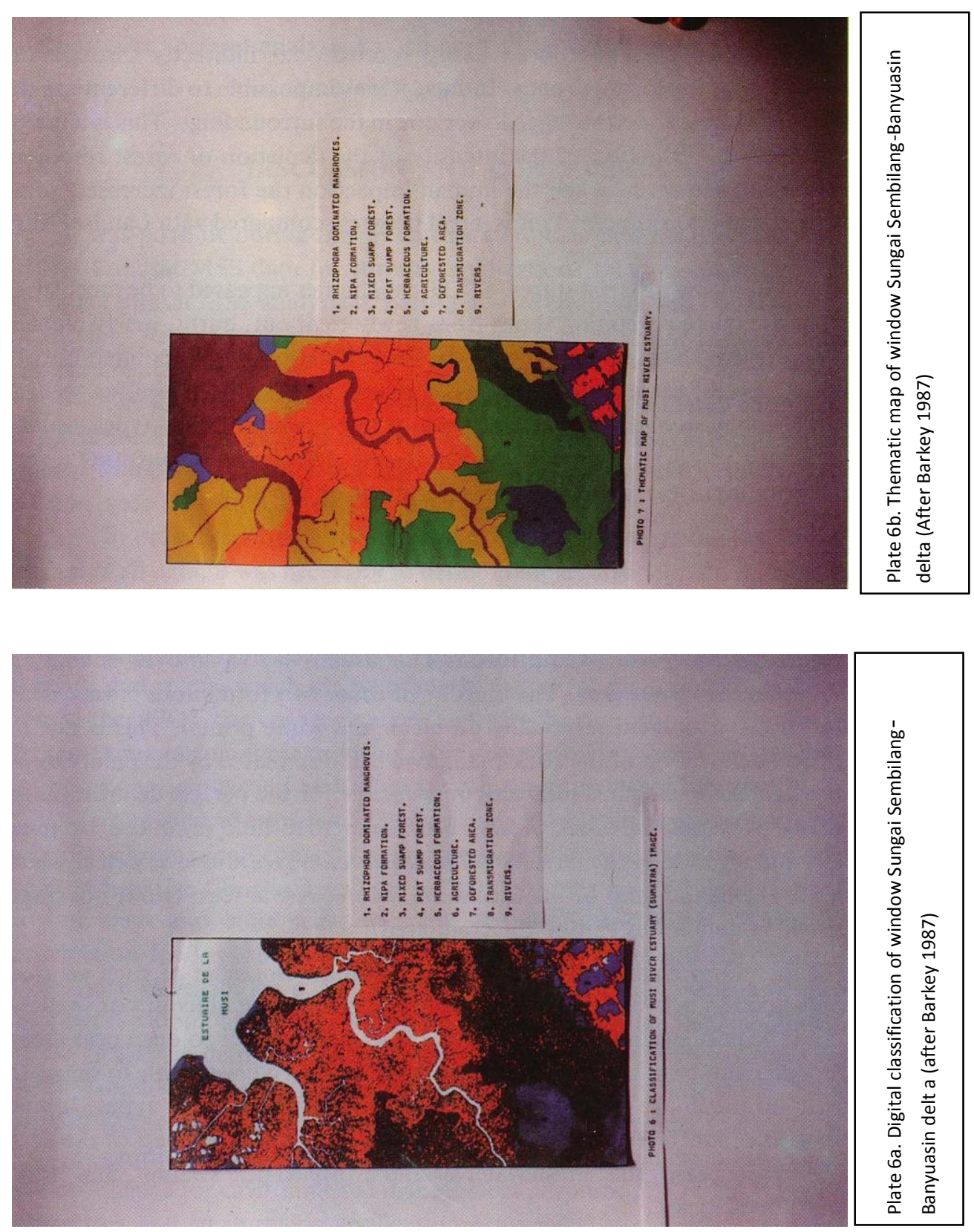
out. Riparian forest types, even along small rivers, have been located with accuracy.

b) The logging activities have been easily spotted, but indirectly through the visualization of the logging roads. In fact, it was impossible to differentiate the undisturbed forest from the logged-over one in the surroundings. This is a major concern for an evaluation of the intensity of the depletion of forest resources in the region. However, when the human impact on the forest increases, some degrees of depletion appear. This is a real progress compared with Landsat MSS documents.

c) For the monitoring of serial stages, SPOT capabilities appeared to be most striking. The complete vegetation series from newly clear-cut, burnt, newly planted to young regrowth stages mixed with rubber cultivation can be pointed out. In addition, several secondary forest types mixed with rubber trees, as well as various shrubby secondary vegetation types or low secondary forest types, usually classified as "mosaics" have been discriminated. These results constitute a very noteworthy input for agricultural development of the area.

\section{Swamps}

a) It has been sometimes difficult in the past to separate the mangrove forest from the adjacent fresh water swamp forest. This usually led to an over estimation of the actual mangrove area. The ecotone of those two formations is very clear on our SPOT document (especially on black and white prints). This is due to the perfect delineation of the back-mangrove belt dominated by the palm Onco-sperma tigillariutn which is indirectly responsible for the perfect delineation of the mangrove area. In other places, back mangrove hills produced by mud lobsters and invaded by the fern Acrostichum aureum give also a very clear white border to the inland limit of the formation. Moreover, at least two if not three mangrove communities can be differentiated.

b) One of the major challenges for the agricultural development of such an area is the distinction between the fresh water swamp forest on alluvium or shallow peat and the peat swamp forest itself on deeper peat soils. Too deep peat areas are very difficult to manage for agricultural purposes. We were able to separate properly on the image the fresh water swamp forest from other types. It was even possible to differentiate several areas according to the thickness of the peat itself by locating easily the "Fresh water swamp", "Mixed peat swamp", and "Peat swamp" forest types. 
c) Natural shrubby or very low forest types, sometimes known as "padang" vegetation do occur in the area and are generally confused with secondary types. The spectral analysis has allowed to separate them perfectly.

\section{DISCUSSION AND CONCLUSION}

It was possible during the present study to compare the usefulness of SPOT XS and Landsat MSS data for forestry applications using research findings from previous Landsat MSS analysis in Baturaja - Martapura area (Ducros - Gambart \& Gastellu Etchegorry 1984; Gastellu - Etchegorry et al. 1985). Some important remarks are stressed below:

- The number of spectral classes that can be discriminated with SPOT XS, i.e. 32, is much larger than the number of spectral classes that can be obtained with Landsat MSS, i.e. 8. This is due not only to the finer spatial resolution but also to better spectral characteristics of SPOT data.

- In order to derive a reliable and precise forest mapping (1:150 000) with Landsat MSS data, it was necessary to define complex algorithms (i.e. multi-textural analysis), whereas far better results are directly obtained with simple photointerpretation of 1:50 000 SPOT imagery.

- The fine resolution of SPOT data allows to map many earth features such as roads and rivers, which are particularly useful for an accurate spatial registration of the SPOT derived documents and provide opportunities for obtaining at the same time cartographic products. Numerous ground control points which could not be recognized in the Landsat image can easily be located in the SPOT image.

- The only advantage of Landsat imagery was its larger synoptic overview.

Panchromatic documents were only available for two scenes and only in the form of negative films at a scale of 1/200 000 since no CCT were available, the existing black and white prints were not very useful for this work as the level of information for vegetation is quite low when compared with XS data.

The high resolution of SPOT has proved to be of high value in field checking for exact location of the image's features (e.g. small football field in a little village). However, this emphasizes the real necessity for a very fast delivery of data for proper use of remote sensing techniques in tropical environment where the character of most of the land-use and vegetation patterns is so dynamic.

Regarding the identification and classification of the humid tropical vegetation in Sumatra for environmental management purposes, SPOT has brought several advantages and encouraging application prospects: 


\section{- Forestry management}

Several forest types, especially within mangrove and swamp forest areas and also in the uplands, have been discriminated with SPOT data. Even if some of the needs cannot be perfectly fulfilled, e.g. proper distinction between primary and logged-over forest, the fact that degrees in the forest depletion can be pointed out will be of great interest to the forester. Considerable improvement in the identification of serial stages will also facilitate the monitoring of reforestation projects.

\section{- Land-use management}

The improvement in the identification of some land uses is also striking. Such possibilities as the distinction between newly clear cut fields, burnt areas, and newly planted food crops, will allow easy monitoring of such areas where the shifting cultivation is an important feature of the landscape.

\section{- Mangrove and swamps management}

The perfect delineation of the mangrove is one of the most beneficial results of SPOT. Many different figures exist concerning the exact mangrove surface in the region. Possibilities of studying on satellite documents what could be the mangrove communities themselves ("Rhizophora type" or "Sonneratia type") was another interesting aspect which should be investigated cautiously. For agricultural management of the peat area, SPOT provides an excellent tool for an indirect evaluation of the thickness of the peat through identification of specific vegetation types.

Many of the identification problems mentioned above could probably be solved by photogrammetry using aerial photographs at scale of 1:5000 to 1:10 000. However, the cost of aerial cover in such remote places prohibits in most cases their use before implementation of development project. Moreover, there were often difficulties in the past for any extrapolation between the general data provided by Landsat MSS, and the detailed features of large scale aerial photographs.

Only simple digital image processing has been applied in this study. It gives nevertheless interesting results and the improvement of multispectral classifications of high resolution data is challenging for site quality assessment through vegetation appraisal. Increased revisiting capabilities and lateral viewing, together with a better accuracy in the localization of samples offer additional opportunities in the data acquisition and processing. The dynamic character of most of the land-use and vegetation patterns implies that ground verification has to be carried out as soon as possible after data recording.

On one hand, the use and interpretation of classes along the "brightness axis" Was interesting and must be worked out in the future for the classification of spectral classes with sparse or non-vegetation cover. On the other hand, the 
"vegetation axis" gives information about the vegetation cover and biomass. The synthesized information that is displayed by Figure 2 is undoubtedly very useful for surveying forested areas, and more especially for estimating the density of the vegetation cover of land cover classes. It can provide preliminary assessment about the vegetation cover of spectral classes that were not identified or checked in the field. Finally, the validity of classes that were supposedly identified either in the field or with aerial photographs can easily be tested. For example, classes corresponding to forested areas should not be located on the "brightness axis".

This study suggests that SPOT is certainly a very good alternative to medium altitude aerial photograph coverage $(1 / 100000,1 / 50$ 000) and emphasizes its value for tropical vegetation mapping at a medium scale (1/100 000 to $1 / 250000)$ since comparisons of the cost of SPOT data versus other remote sensing tools (Hadjar 1987, Antikidis et al. 1988) give also a striking advantage to SPOT.

\section{ACKNOWLEDGMENTS}

This study was conducted as a part of the research project supported by the PEPS Program (Programme d' Evaluation Preliminaire de SPOT) of the French Space Agency, in cooperation with ICIV, Toulouse and SEAMEO-BIOTROP, Bogor.

The authors would like to thank Dr. J.P. Gastellu-Etchegorry and Dr. R.A. Barkey for their contributions in the digital treatments of the Martapura and Sungai Sembilang regions.

\section{REFERENCES}

ANTIKDIS, J.P., A. HUDSON and J.P. GASTELLU-ETCHEGORRY 1988. A SPOT/LANDSAT receiving station in Indonesia S.C.O.T. report. 57pp.

BARKEY, R.A. 1987. Etudes des mangroves de L' Indo-Malaisie et application des techniques de la tele-detection a Sulawesi. These Doctorat de L'UPS, ICIV Toulouse, France.

BIOTROP-BAKOSURTANAL 1988. Pemetaan vegetasi daerah Baturaja, Propinsi Sumatra Selatan. Skala 1:250 000. Laporan kerjasama SEAMEO-3IOTROP dengan BAKOSURTANAL.

BLASCO, F., Y. LAUMONIER and PURNADJAJA 1983. Tropical vegetation mapping: Sumatra. BIOTROP Bull, in Tropical Biology. No. 22.

DESHAYES, M. 1981. Traitement numerique des donnees Landsat. Application a la cartographic automatique de la vegetation tropicale. These Docteur-Ingenieur, UPS-ICIV, Toulouse.

DJAILANY, U.R. 1987. Formations vegetales naturelles de Sumatra (Indonesia): structure et caractristi-ques radiometriques. These Doctorat, de L'UPT, ICIV, Toulouse, France. 
DUCROS-GAMBART, D. and J.P. GASTELLU-ETCHEGORRY, 1984. Automatic analysis of bi-temporal Land-sat data: application to the study of the evolution of vegetation-covered areas in a tropical region. IGARSS symp., ref. ESA SP-215: 187-192.

DUCROS-GAMBART, D., T. L.E TOAN and M. DESHAYES 1984. Utilisation des donnees Landsat pour la cartographic des formations ve'getales tropicales dans le sud de Sumatra. L'Espace Ge'ographique, n³, 205-214, 290.

GASTELLU-ETCHEGORRY, J.P. 1988. Remote sensing with SPOT; An assessment of SPOT capability in Indonesia. Gadjah Mada University Press. Yogyakarta.

HADJAR, N. 1987. Forest observation by satellite. Paper presented at the ACRS, Jakarta, A - 16/1 - 13.

LAUMONIER, Y. 1981. Classification of Southern Sumatra forest types. BIOTROP unpublished report.

LAUMONIER, Y. 1983. International Map of the Vegetation, scale 1:1 000 000; sheet Southern Sumatra. BIOTROP, Bogor, ICIV, Toulouse.

LAUMONIER, Y., PURNADJAJA and SETIABUDI 1986-87. International Map of the Vegetation, scale 1:1000 000; sheet Central Sumatra (1986), sheet Northern Sumatra (1987). BIOTROP, Bogor; ICIV, Toulouse.

LAUMONIER, Y. U.R. DJAILANY, J.P. GASTELLU-ETCHEGORRY and R. BARKEY 1987. Assessment of SPOT satellite based system in Tropical vegetation identification, classification and monitoring in Sumatra (Indonesia). SPOT first result in flight conference, Paris Nov. 87. CNES. p ?

PURNADJAJA 1980. Evolution de la vegetation 1969- 1976 dans la region de Palembang, Sumatra, Me'moire DEA, UPS-ICIV, Toulouse.

RICHARDSON, A.J. and C.L. WIEGAND 1977. Distinguishing vegetation from soil background information. Photogram. Eng. and Remote Sens. 43(2): 207 - 216.

ROUSE, J.W., R.H. HAAS, J.A. SCHELLand D.W. DEERING 1973. Monitoring vegetation systems in the great plains with ERTS. 3rd ERTS Symp., NASA SP-351, 1:309-317.

TORQUEBIAU, E.F. 1986. Mosaic patterns in dipterocarp rain forest in Indonesia and their implications for practical forestry. J. of Trop. Ecol. 2:301 - 325.

TUCKER, C.J. 1977. Spectral estimation of grass canopy variables. Remote Sens, of Environment, 6: 11-26. 


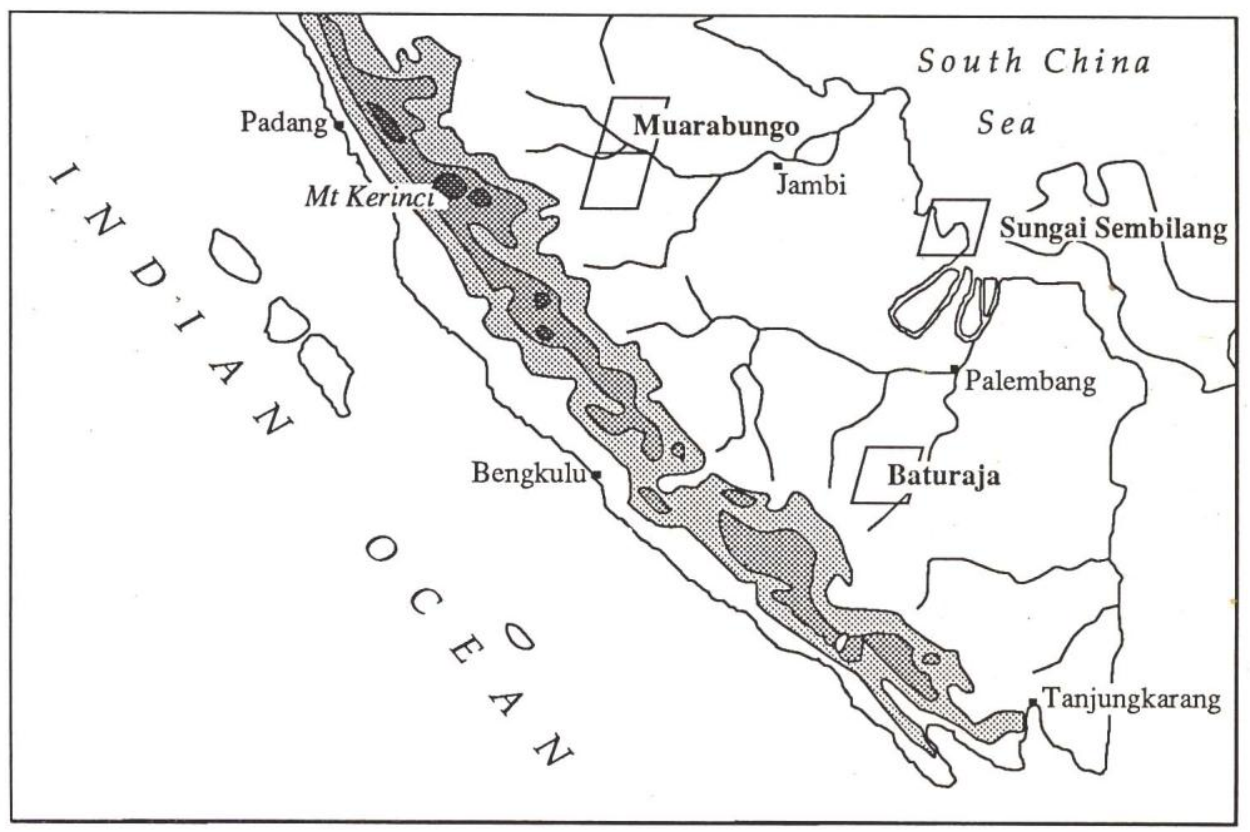

Figure 1. Location of study areas

Table 1. Requested products and acquisition scored

\begin{tabular}{|c|c|c|c|c|c|c|}
\hline \multirow{2}{*}{ Muarabungo } & \multirow{2}{*}{$\begin{array}{l}\text { K } 272 \\
\text { J } 353\end{array}$} & $\mathrm{XS}$ & 0000 & CCT and film 1/200 000 & $6^{\prime} 2 \mathrm{w}$ & 7.20 .86 \\
\hline & & $\mathrm{P}$ & 0000 & film $1 / 200000$ & $6^{\prime} 2 \mathrm{w}$ & 7.20 .86 \\
\hline \multirow{2}{*}{ Pasirmayang } & \multirow{2}{*}{$\begin{array}{l}\text { K } 272 \\
\text { J } 353\end{array}$} & XS & 0000 & CCT and film 1/200 000 & $6^{\prime} 2 \mathrm{w}$ & 7.20 .86 \\
\hline & & $\mathrm{P}$ & 0000 & film $1 / 200300$ & $6^{\prime} 2 \mathrm{w}$ & 7.20 .86 \\
\hline \multirow{2}{*}{ Sungai Sembilang } & \multirow{2}{*}{$\begin{array}{l}\text { K } 272 \\
\text { J } 353\end{array}$} & $\mathrm{XS}$ & 1010 & CCT and film $1 / 200000$ & $22^{\prime} \mathrm{w}$ & 7.21 .86 \\
\hline & & $\mathrm{P}$ & - & film $1 / 200000$ & - & not acquired \\
\hline \multirow{2}{*}{$\begin{array}{l}\text { Baturaja- } \\
\text { Martapura }\end{array}$} & \multirow{2}{*}{$\begin{array}{l}\text { K } 272 \\
\text { J } 353\end{array}$} & $\mathrm{XS}$ & 0000 & CCT and film 1/200 000 & $22^{\prime} \mathrm{w}$ & 7.21 .86 \\
\hline & & $\mathrm{P}$ & - & film $1 / 200000$ & - & not acquired \\
\hline
\end{tabular}


Both visual and digital analysis techniques have been used. Vegetation sketch maps and land cover classifications were prepared by manual interpretation of black and white XS or standard false colour composite prints at scales varying from 1/50 000 to $1 / 100$ 000. For mangroves and swampy areas, other false colour combinations have been used such as XS2 - Bi - Vgi or XS1 - PCI - PC2.

A supervised multispectral classification was performed simultaneously using a Pericolor 1000 system in France and an IBM AT/XT system in Indonesia, by simple visualization of each band using gray scales or colour table and simple transformations, such as band ratios, vegetation indices and principal component analysis. The procedure is similar to the information on techniques extracting developed for soil and leaf area indices (Richardson \& Wiegand 1977; Tucker 1977; Rouse et al. 1973). Means, standard deviation, range of radiance values as well as coefficient of correlation for the 3 bands were computed for all samples, together with covariance matrix of all classes to assess the value of the classification. To facilitate the visualization of the field site data, XS1, XS2 and XS3 means and standard deviations were plotted on bi-dimensional diagrams. All classes have been checked in the field (one year after data acquisition by the satellite) and eventually redefined.

\section{RESULTS}

\section{Baturaja - Martapura}

The original vegetation is much degraded with typical huge areas of grasslands dominated by Imperata cylindrica, various stages of shrub savannas and pseudoclimactic forest type dominated by Schima wallichii. Some very degraded remnants of the original forest types and a land-use composed of irrigated or rainfed paddy fields, orchards, rubber plantations, "damar" plantations and reforestation areas are other important features of the landscape.

Some small depressions are common along the streams. A rather large one is found north east of the scene, around lake (Lebak) Datuk. The water level in these depressions fluctuates considerably and during the dry season they are mostly dry.

\section{A. Visual interpretation}

The classification produced is given in Table 2 . These results were used to produce an ecological vegetation map at a scale of 1/250 000 at the request of the Indonesian National Coordination Agency for Survey and Mapping, the BAKOSURTANAL. A total of 23 types were identified and used later as legend of the published map (BIOTROP - BAKOSURTANAL 1988). 
Table 2. Classification of the vegetation in Martapura region by visual interpretation

1. Very depleted lowland forest (high secondary forest with remnant primary forest tree species)

2. High secondary forest (often mixed with rubber)

3. Mosaic of high secondary forest and food crop cultivation

4. High secondary forest dominated by Schima wallichii

5. Shrub, secondary regrowth

7. Grassland

8. Swampy tall secondary vegetation dominated by Melaleuca $\mathrm{sp}$.

9. Swampy shrubby vegetation

10. Swampy grassland dominated by Cyperaceae

11. Rubber estate

12. Coffee gardens, often overtopped by fruit trees, mixed with food crop fields

13. Pepper gardens

14. Orchards, fruit trees

15. Newly opened field for rubber and oil palm estate

16. Dry fields, food crops, mixed with secondary regrowth

17. Village, habitat and fruit trees

18. Rice field

\section{B. Digital classification}

The analysis of visual displays of SPOT data provided the selection of thirty two SPOT spectral classes. Computer screen displays of enhanced SPOT data and SPOT photographic products at a 1/100 000 scale of bands XS1, XS2 and XS3 allowed the identification of most of them. However, some classes (20 to 31) could be distinguished only during digital processing stages (density slicing, image enhancement, etc.). They were not detected with conventional photo-interpretation, and the question of their real existence also arises since, unfortunately, most of these classes could not be identified properly. However, qualitative values of the density of their biomass were tentatively assessed with the aid of techniques developed for extracting information on soil and leaf area indices (Rouse et al. 1973; Richardson \& Wiegand 1977; Tucker 1977). They can be classified as "sparse vegetation" $(29,30,31)$, "rather sparse vegetation" $(26,27,28)$, "vegetation" (22, 23, 24, 25) and "green vegetation" $(20,21)$.

The 32 classes and their characteristics are presented below (Gastellu-Etche-gorry 1988): They are grouped per land cover type and according to their relative position on the "vegetation axis".

\section{Forest}

(1) Primary Forest: tall trees up to 45 - $55 \mathrm{~m}$. Compared to other classes, it is characterized by the smallest XS1 and XS2 radiometric values; i.e. highest absorption by vegetation. 
(2) Very depleted forest: result of former exploitation of primary forest followed by local depletion.

(3) Remnant primary forest and secondary growth: external features (roads, etc.) reveal some degradation. Radiometries in bands XSI and XS2 are slightly larger than those of (1).

(4) Remnant primary forest and secondary growth. The proportion of primary forest is less important than that of (3).

(5) Swamp vegetation: Small XS3 radiometric values: XSI and XS2 radio-metric values are larger than those of dry land forests. A "spotted" textural pattern may reveal the presence of the swampy areas.

\section{Secondary Forest}

(6) Old tall secondary forest: compared to (7), the trees and texture are similar but the vegetation index (i.e. leaf area index and/or biomass density) is larger.

(7) Tall secondary forest: taller and older than (8); texture may be similar to that of (10).

(8) Low secondary forest: compared to primary forest, the XSI and XS2 radiometric values are larger and the XS3 radiometric values are similar.

(9) Low secondary forest: successional stage before (8), younger and smaller.

\section{Rubber Plantation}

(10) Rubber plantation: homogeneous aspect on XSI and XS2 imageries. It is identified thanks to the presence of roads that usually display a geometric pattern.

(11) Young rubber plantation: successional stage after (12).

(12) Newly planted rubber trees: XSI radiometric values are between those of rubber plantation and secondary forest growth, whereas its XS3 radiometric values are smaller than those of rubber plantation, primary forest and secondary forest.

\section{Settlements and mixed gardens}

(13) Fruit tree gardens: close to settlements; should be verified in the field.

(14) Gardens and sparse vegetation cover (alang-alang grasses).

\section{Shrubs, herbaceous vegetation and bare soil}

(15) Herbaceous vegetation: vegetational stage after (17), it is more densely vegetated (larger vegetation index). 
(16) Shrubs and thicket vegetation.

(17) Sparse vegetation cover: bare soil and more or less sparse herbaceous vegetation.

(18) Recently opened area: vegetational stage before (17).

(19) Bare soil.

Non-identified land cover units (assessed through their respective vegetation index; leaf area! index/biomass):

(20), (21) Green vegetation

(22), (23), (24), (25) Vegetation

(26), (27), (28) Rather sparse vegetation

(29), (30), (31) Sparse vegetation.

\section{Water (32)}

Moreover, Figure 2 shows that some spectral classes which share similar spectral characteristics cannot be reliably discriminated by spectral analyses only

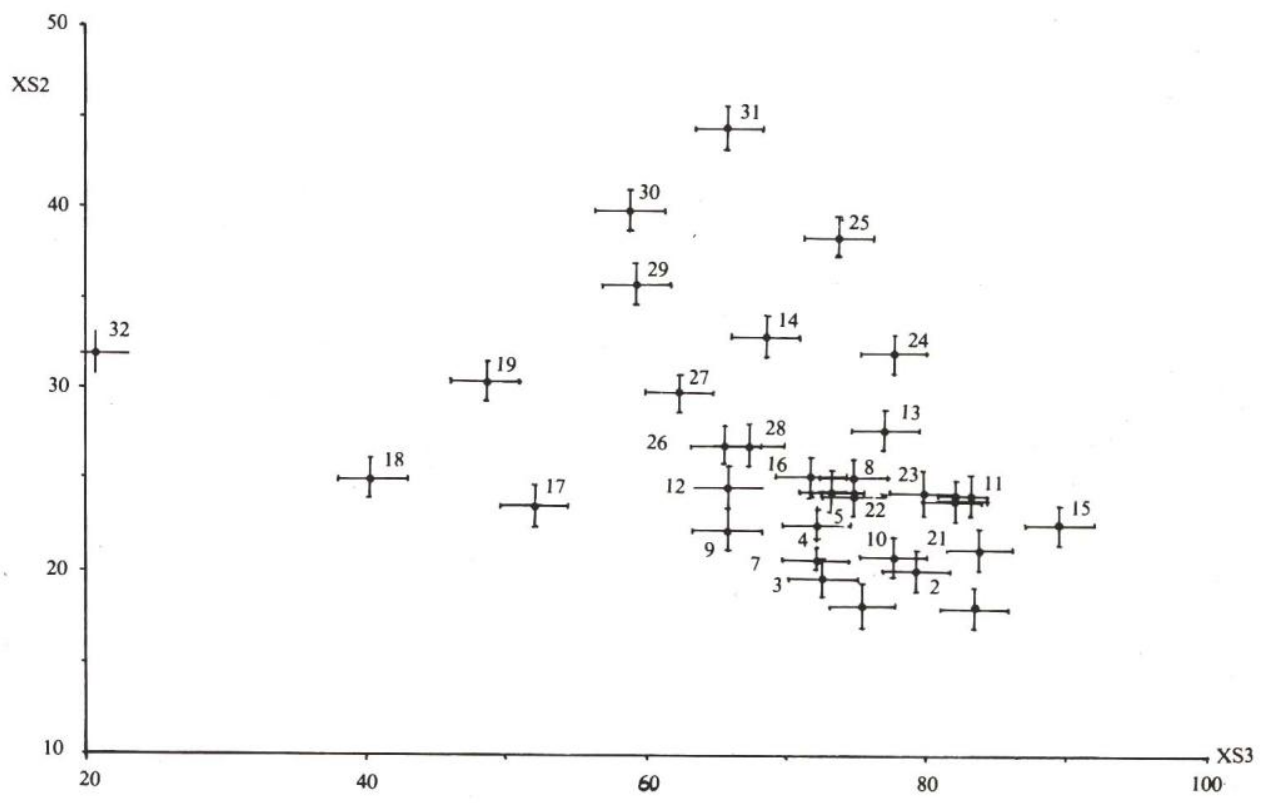

Figure 2. XS3/XS2 diagram of the 32 spectral classes selected in Martapura scene. 
i.e. classes (26) and (28), (21) and (11), (8) and (22), etc. In this case, knowledge of the field (if any) and the spatial and textural information which can be extracted from simple photo interpretation of SPOT XS1, XS2 and XS3 imageries must also be inputed (Gastellu - Etchegorry 1988).

In this study, the identification of these classes obviously required additional field checks which were conducted in June 1988. Plate 1 and Table 3 give an example of the reformulation of the 32 classes for one "window of the Martapura scene", after field work. Only 13 classes (11 vegetation types) were actually identified for that particular area, which means that several spectral values correspond actually to one vegetation types. Classes 5,8,22,23,26 and 28 for instance, should be regrouped into class 7 e.g. grasslands, at least as far as identification of the types is concerned.

Table 3. Digital classification of window Batu Marta, Martapura

\begin{tabular}{|c|c|c|c|c|c|}
\hline & Vegetation types & Pixels & $\begin{array}{l}\text { Surface } \\
\text { (ha) }\end{array}$ & $\begin{array}{l}\text { Percentage } \\
(\%)\end{array}$ & Colour \\
\hline 0 & $\begin{array}{l}\text { Unclassed and home- } \\
\text { stated mixed gardens } \\
\text { (settlement) }\end{array}$ & 14926 & 597.04 & 4.8 & black \\
\hline 3 & $\begin{array}{l}\text { Secondary forest } \\
\text { mixed with rubber }\end{array}$ & 40617 & 1624.68 & 13.2 & $\begin{array}{l}\text { whitish } \\
\text { bright }\end{array}$ \\
\hline 4 & $\begin{array}{l}\text { Low secondary forest } \\
\text { and Schima wallichii }\end{array}$ & 59524 & 2380.96 & 19.4 & $\begin{array}{l}\text { bright } \\
\text { green }\end{array}$ \\
\hline 6 & $\begin{array}{l}\text { Shrub, secondary } \\
\text { regrowth (newly } \\
\text { felled) }\end{array}$ & 4235 & 169.4 & 1.4 & $\begin{array}{l}\text { whitish } \\
\text { grey }\end{array}$ \\
\hline 7 & Grassland & 52676 & 2107.04 & 17.1 & yellow \\
\hline 8 & Rubber tree estate & 93328 & 3733.12 & 30.4 & red \\
\hline 9 & $\begin{array}{l}\text { Swampy shrubby } \\
\text { vegetation }\end{array}$ & 10737 & 429.48 & 3.5 & orange \\
\hline 11 & $\begin{array}{l}\text { Dry field, food crop, } \\
\text { mixed with secondary } \\
\text { regrowth }\end{array}$ & 12398 & 495.92 & 4 & $\begin{array}{l}\text { dark } \\
\text { green }\end{array}$ \\
\hline 12 & $\begin{array}{l}\text { Longtime burnt and } \\
\text { slightly covered by } \\
\text { regrowth }\end{array}$ & 6900 & 276 & 2.3 & $\begin{array}{l}\text { dark } \\
\text { grey }\end{array}$ \\
\hline 13 & $\begin{array}{l}\text { Recently burnt for } \\
\text { estate area }\end{array}$ & 7828 & 313.12 & 2.5 & brown \\
\hline 14 & Swampy area & 2388 & 95.52 & 0.8 & violet \\
\hline 17 & River & 811 & 32.44 & 0.3 & blue \\
\hline 18 & $\begin{array}{l}\text { Sand sediment in the } \\
\text { river }\end{array}$ & 782 & 31.28 & 0.3 & $\begin{array}{l}\text { bright } \\
\text { blue }\end{array}$ \\
\hline
\end{tabular}




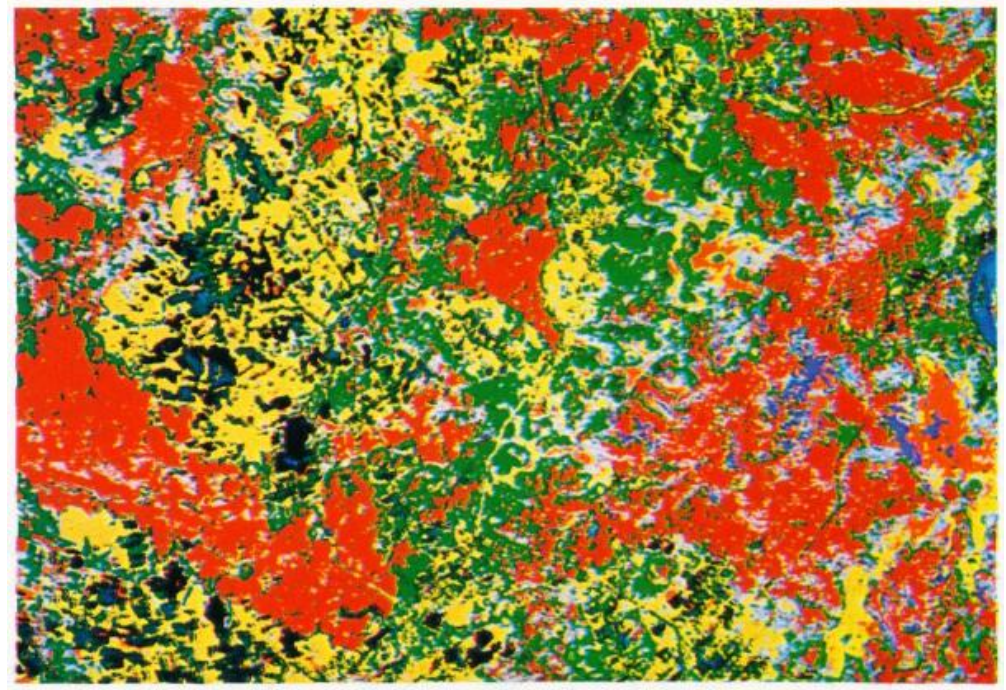

Plate 1. Digital classification of window Batu Marta, Martapura

\section{Muarabungo - Pasirmayang}

A very peculiar land-use feature is found there. Local people have grown rubber trees since 1910. After about two years of rice cropping, the field is planted with rubber trees and it gradually becomes a secondary forest mixed with rubber which is rarely cleaned but still used for tapping. This leads to various stages of secondary forests mixed with rubber which are impossible to differentiate from pure serial stages on remote sensing documents. The area still harbours pieces of quite undisturbed forest and large tracks of logged over forests. The landscape is also characterized by large transmigration areas.

In that area, remote sensing encountered problems in identifying and classifying the following vegetation and land cover types:

- the mosaic nature of the primary lowland forest: the tropical forest is highly dynamic and grows in patches, a mosaic of higher and lower forest parts which have their origin in the natural fall of trees or part of the tree crowns.

- the locally depleted forest (local exploitation) and the really undisturbed ones (only industrial logging is recognizable but only indirectly through the visualization of the logging roads).

- low secondary forest types mixed with rubber tree cultivation (managed by local farmers) and pure serial stages without human interferences. 